\title{
An Analysis of Symbolism in the Five Selected Love Poems of Nicholas Gordon
}

\author{
Masagus Sulaiman \\ Universitas Muhammadiyah Palembang \\ (masagussulaiman@ymail.com)
}

Submitted: 2019-03-12

Accepted: 2019-03-20

Approved: 2019-04-19

\section{Key Words:}

Symbolism, Poem, Rhythm

\section{Kata Kunci:}

Simbolisme, Puisi, Ritme

\section{ABSTRACT}

This research is aimed at figuring out the dominant symbolisms and the meanings in the five selected love poems of Nicholas Gordon. The descriptive-qualitative method was applied in this research. To analyze the data, the researcher used qualitative data analysis. The results showed that there were twenty five conventional symbolisms and nineteen natural symbolisms in the five selected love poems of Nicholas Gordon. In other words, four conventional symbolisms and four natural symbolisms in the first selected love poem, four conventional symbolisms and eight natural symbolisms in the second selected love poem, ten conventional symbolisms and one natural symbolism in the third selected love poem, four conventional symbolisms and three natural symbolisms in the fourth selected love poem, and three conventional symbolisms and three natural symbolisms in the fifth selected love poem. In conclusion, conventional symbolism was more dominant than natural symbolism, and most of the meanings of the poems related to feelings of happiness and sadness in line with love relationship.

\section{ABSTRAK}

Penelitian ini bertujuan untuk mengetahui simbolisme yang dominan muncul dan makna yang ada dalam lima puisi cinta pilihan Nicholas Gordon. Metode deskriptifkualitatif diterapkan dalam penelitian ini. Peneliti menggunakan analisis data kualitatif untuk menganalisa data. Hasil penelitian menunjukkan bahwa ada dua puluh lima simbolisme konvensional dan sembilan belas simbolisme alami dalam lima puisi cinta pilihan Nicholas Gordon. Dengan kata lain, empat simbolisme konvensional dan empat simbolisme alami dalam puisi cinta pilihan pertama, empat simbolisme konvensional dan delapan simbolisme alami dalam puisi cinta pilihan kedua, sepuluh simbolisme konvensional dan satu simbolisme alami dalam puisi cinta pilihan ketiga, empat simbolisme konvensional dan tiga simbolisme alami dalam puisi cinta pilihan keempat, dan tiga simbolisme konvensional dan tiga simbolisme alami dalam puisi cinta pilihan kelima. Kesimpulannya, simbolisme konvensional lebih dominan daripada simbolisme alami, dan sebagian besar makna puisi berhubungan dengan perasaan bahagia dari sebuah hubungan cinta.
Masagus Sulaiman

An Analysis of Symbolism in the Five Selected

Love Poems of Nicholas Gordon
ALSUNA Vol. 2 (1), 2019

http://e-journal.ikhac.ac.id/index.php/alsuna https://doi.org/10.31538/alsuna 


\section{Introduction}

At the beginning of this research writing, it is much better to delineate what language refers to. Language refers to the system of human communication which consists of the structural arrangement of sounds (their written representation) into large units, e.g. morphemes, words, sentences, utterances, etc." (Richards, Schmidt, Kendricks \& Kim (2002, p.283). Furthermore, Brown (2007) says that language is a set of arbitrary symbol of primarily vocal but may also be visual, having conventionalized meanings to which they refer, being used for communication operating in a speech community or culture. Being essentially human althouh possibly not limited to humans and being acquired by all people in much the way; language and language learning both have universal characteristics, including such systems of phonemes, morphemes, phrases, clauses and context. (p. 6). In brief, the researcher thinks that language reflects human beings' expressions in daily life.

One of the language components is that literature. Ade and Okunoye (2008) define literature as certain facts, for instances: imaginative, life experiences, words in a powerful, effective and yet captivating manner, and recreation and revelation of hidden facts. (p. 2-3). On the other side, Hornby (2010) deciphers literature as creative the writing or the study of books, valued as works of arts (drama, fiction, essay, poetry) constrasted with technical books and journalism. (p. 572). In addition, Robert \& Jacob (1982) itemize literature as one of the interesting human's works in term of art in written language. Robert \& Jacob (1982) further state that:

\section{"Literature can increase personality and intelectuality; it serves knowledge and interesting goals; it makes people know the other cultures; philosophy and religious world where was as a part of it and it is possible for them to identify ideas and competition in different places and times which have never been known."}

Like other experts, Abrams \& Harpham (2009) say that literature derives from latin word "litteraturae" which means writing and commonly used in 18th century to designate fictional and imaginative writing as in poetry, prose fiction and drama. (p. 177-178). In conclusion, literature has something to do with human's masterpiece of writings which carry some ideas in the forms of feelings, expressions and values, and regarded as imagination. Learning literature means learning literary works. As one of the well-known literary works, a poem has taken

Masagus Sulaiman

An Analysis of Symbolism in the Five Selected Love Poems of Nicholas Gordon http://e-journal.ikhac.ac.id/index.php/alsuna https://doi.org/10.31538/alsuna 
important parts in mankind's brains due to building real life awareness and comparing to literary work itself as a reflection of the bliss or pains. Childs \& Fowler (2006) state that poem is any composition in verse: referring to a set of technical conventions for regulating a composition by line-length, for making the line part of the expressive form, and claiming to be a genre-term subsuming any production which utilizes that convention (p. 181)

In addition, Baldick (2001) assumes that poem or poetry is language sung, chanted, spoken or written based on some pattern of recurrence that emphasizes the relationship between words on the basis of sound as well as sense and this pattern is almost always a rhythm or metre which may be supplemented by rhyme or alliteration or both. (p. 198). On the other side, Mikics (2007) states that poem or poetry is from Greek "poiein" which has something to do with the work of a poet seen as a maker of imaginative literature. (p. 237-238). It can be presumed that a poem or poetry is such language harmony which shows the beauty of arts.

Moreover, Cuddon (2013) elaborates that:

"poem as any other kinds of compositions an a species of magic, the secret to which lies in the way, the words lean upon each other, are linked and interlocked in sense and rhythm and thus elicit from each other's syllable as a kind of tune whose beat and melody varies subtly and which is different from that of prose." (p. 559)

In this research, the researcher concludes that poem is like a literary work in the form of composition that can be interpreted as rhtyhm or harmony. One of the important parts stated in a poem is that symbolims or symbols. Cuddon (2013) states that symbolism is from Greek symballein and symbolon means throw together or mark, emblem, or sign. It is an object, animate or inanimate, which represents something else. (p. 699). Abrams (1999) also adds symbolism or symbols refer to conventional or public, such as the Red and the Good Shepherd refer to symbolic objects which determinate a particular culture. (p. 311)

According to Quinn (2006) symbolism or symbol is such a widely used term in many disciplines, referring to the process by which a person, place, object, or event comes to stand for some abstract idea or condition. (p. 408). Cirlot (2001) illustrates some instances of some common symbolims or symbols often stated in a poem, as follows:

Masagus Sulaiman

An Analysis of Symbolism in the Five Selected Love Poems of Nicholas Gordon http://e-journal.ikhac.ac.id/index.php/alsuna https://doi.org/10.31538/alsuna 
1. Air and fire which symbolize an active one and male. (p. 6)

2. Water and earth which symbolize a passive one and female. (p. 6)

3. Ant symbolizes a soothsaying. (p. 14)

4. Night symbolizes passive principle, the feminine and the unconscious. (p. 228)

5. Stone symbolize being, of cohesion and harmonious reconciliation, the laws of change, decay and death. (p. 313)

6. Tree symbolizes the life of the cosmos: its consistence, growth, proliferation, generative and regenerative processes as well as immortality. (p. 346-347)

As the matter of facts, so many people especially readers or students who read a poem, they only read it for fun, yet not all of them are familiar with symbolism (symbols) which are available in the poems. They even do not know the meanings or probably the poet who made it and some other poems of his or her great masterpieces. From this problem or phenomenon, the researcher was keen on conducting a research under the title "An Analysis of Symbolism in the Five Selected Love Poems of Nicholas Gordon". The reasons why the researcher chose the five selected poems of Nicholas Gordon because of his popularity as a great well-known love poet in the world, and also his love poems were accessible and free for downloading. Another reason was that the five selected poems were so familiar and interesting to read, as well as straightforward to be analyzed and containing a lot of symbolism or symbols that can be scrutinized. One instance of love poem written by Nicholas Gordon which has some symbolism, as in:

Each truth is just a scrim across the darkness.

We cannot see what most we'd like to know.

We drive among sheer cliffs in pale moonlight

Unsure of where we are or where to go.

When we allow our heads to make our choices,

We lose because of what we cannot see.

When we give way and let desire take us,

We lose because we want what cannot be.

Masagus Sulaiman

An Analysis of Symbolism in the Five Selected

Love Poems of Nicholas Gordon
(4)

http://e-journal.ikhac.ac.id/index.php/alsuna https://doi.org/10.31538/alsuna 
We inch along the dream-lit rocky ridges

Knowing always, always we must lose.

The end for all is darkness everlasting,

And so it matters less which road we choose.

What matters is the beauty of sheer being;

The gifts we have and those we will become;

The ecstasy of loving so completely

That we ourselves are more than minds can plumb.

Love well and know that love must end in pain.

Be a fool and pay the unmarked price.

Be generous of self, and passion gain:

One who never loses, loses twice. (Gordon, 2006)

From the above stated love poem, it was known that there were some symbolims or symbols, such as darkness which symbolizes mystery of something or someone. Pale moonlight which symbolizes doubts and hopeless. Sheer cliffs which symbolizes an obstacle in determining life. Rocky ridge symbolizes hictic time or hardest time of life. Road which symbolizes journey and destination. Beauty of Sheer which symbolizes mirage of something beautiful. Road which symbolizes journey and destination. Ecstasy of loving which symbolizes happy feeling, and Unmarked Price which symbolizes unexpected risk in life. In brief, the researcher believes that this research can be beneficial for anyone who reads it to develop his or her understanding about symbolisms in poems.

\section{Method}

The method of the research that the researcher used in this research was a descriptivequalitative method in line with describing the facts in terms of words and phrases and not related to numerical numbers. In other words, the researcher described the existing information or data about symbolism inside the poems. It was supported with a theory of descriptive

Masagus Sulaiman

An Analysis of Symbolism in the Five Selected

Love Poems of Nicholas Gordon http://e-journal.ikhac.ac.id/index.php/alsuna https://doi.org/10.31538/alsuna 
research by Tavakoli (2012) who states that a descriptive research is similar to qualitative research because it deals with naturally occurring phenomena, using data which may either be collected first hand or taken from already existing data sources. (p. 161).

In addition, the data that the researcher obtained was through documentation technique. According to Indawan, Sulaiman \& Susanti (2017) documentation is a technique used to collect the existing data by writing the stable sources used to be an evidence, not reactive but naturalistics, and it is not limited by the space and time. (p. 84). In this case, the researcher did some procedures, such as searching the five selected love poems of Nicholas Gordon on internet, and downloaded. Then, the researcher read them by highlighting the symbolims inside the poems.

After the data was collected, the researcher analyzed them through qualitative data analysis based on the theory of Cirlot (2001). In addition, Hamilton \& Pinnegar (2009) state that qualitative data analysis involves the organization, classification, and categorization along with a search for patterns and a synthesis of pattern in recursive. (p.148). In this context, the researcher applied some procedures such as classifiying the symbolism stated in the five selected love poems of Nicholas Gordon, then analyzing the meanings, transcribing and making a conclusion.

\section{Findings}

\section{Symbolism in the Five Selected Love Poem of Nicholas Gordon}

In this research, the researcher analyzed five love poems, and found some symbolisms or symbols in terms of conventional symbolism and natural symbolism. To be detailed, Table 1 describes symbolisms in the 1st selected love poem of Nicholas Gordon.

\begin{tabular}{|l|l|c|c|}
\hline \multicolumn{1}{|c|}{ Title } & \multicolumn{1}{c|}{ Verse } & \multicolumn{2}{c|}{ Symbols Found } \\
\cline { 3 - 4 } & $\begin{array}{l}\text { After love and fear, there's pride; } \\
\text { After tears, the night; } \\
\text { After all the words are gone, } \\
\text { A chair with just one light. }\end{array}$ & 1 & CS \\
\hline $\begin{array}{l}\text { After love and fear, } \\
\text { there's pride }\end{array}$ & \begin{tabular}{l} 
After memories, the dream \\
\hline
\end{tabular} & 1 & 1 \\
\hline
\end{tabular}

Masagus Sulaiman

An Analysis of Symbolism in the Five Selected Love Poems of Nicholas Gordon
ALSUNA Vol. 2 (1), 2019

http://e-journal.ikhac.ac.id/index.php/alsuna https://doi.org/10.31538/alsuna 


\begin{tabular}{|l|l|c|c|}
\hline & $\begin{array}{l}\text { That you will come home safe; } \\
\text { After sleep, another day } \\
\text { Of waiting for my life. } \\
\text { After hope, the happiness } \\
\text { Of thinking of your love; } \\
\text { After moments of despair } \\
\text { A stone no thought can move. } \\
\text { After love and fear, } \\
\text { there's pride }\end{array}$ & $\begin{array}{l}\text { After all the sacrifice, } \\
\text { The hunger and the pain, } \\
\text { The passions and the promises, } \\
\text { The losses and the gains, } \\
\text { There's nothing but my love for you, } \\
\text { Which waits upon the wind } \\
\text { To bring you from the barricades } \\
\text { That now you must defend. }\end{array}$ & 1 \\
\hline
\end{tabular}

Note: CS (Conventional Symbolism), NS (Natural Symbolism)

Table 1. Symbolisms in the 1st Love Poem of Nicholas Gordon

Table 1 shows four conventional symbolisms and four natural symbolisms. The four conventional symbolisms refer to tears, dream, home and barricades, while the four natural symbolisms relate to night, light, stone and wind. In this context, tears were stated in the first stanza and in the second line which symbolizes sadness or feeling numb or gloomy. Dream was stated in the second stanza and in the first line which symbolizes fantasy feeling for bright future. Home was stated in the second stanza and in the second line which symbolizes place of comfortable heart and barricades were stated in the fifth stanza and in the third line which symbolizes confined feeling.

In addition, night was stated in the first stanza and in the second line which symbolizes the unconscious vacuous feeling. Light was stated in the first stanza and in the fourth line which symbolizes a better hope for future. Stone was stated in the third stanza, and in the fourth line which symbolizes the decay or death. Wind was stated in the fifth stanza and in the second line which symbolizes the power of spirit in sustaining of life. Other conventional and natural 
symbolisms can be also found in the 2 nd love poem of Nicholas Gordon. To be vivid, Table 2 presents symbolisms in the 2nd love poem of Nicholas Gordon.

\begin{tabular}{|c|c|c|c|}
\hline \multirow{2}{*}{ Title } & \multirow{2}{*}{ Verse } & \multicolumn{2}{|c|}{ Symbols Found } \\
\hline & & $\mathrm{CS}$ & NS \\
\hline Do not love me yet & $\begin{array}{l}\text { Do not love me yet, for I } \\
\text { Am still a slender moon, } \\
\text { A scimitar about the heart } \\
\text { Too sharp to touch too soon. } \\
\text { Before I'm touched I need to grow } \\
\text { More full in golden light; } \\
\text { I need to smile upon my earth } \\
\text { And rule some patch of night. }\end{array}$ & 2 & $\begin{array}{l}1 \\
1 \\
1\end{array}$ \\
\hline Do not love me yet & $\begin{array}{l}\text { I need to know what roads and fields } \\
\text { Lie in my domain } \\
\text { And dull my brand new ecstasies } \\
\text { With sophomoric pain. } \\
\text { I need the love of some blank boy } \\
\text { As cold and dark as me, } \\
\text { That we might grope in ignorance } \\
\text { And fear of what might be. } \\
\text { And then, when I'm a silver bowl } \\
\text { And know what I can hold, } \\
\text { Then, then, perhaps, we could try love } \\
\text { If you are not too old. }\end{array}$ & 1 & 2 \\
\hline
\end{tabular}

Note: CS (Conventional Symbolism), NS (Natural Symbolism)

Table 2. Symbolisms in the 2nd Love Poem of Nicholas Gordon

Table 2 shows four conventional symbolism and eight natural symbolisms. The four conventional symbolisms were scimitar, heart, patch, and silver bowl, while, the eight natural symbolism were moon, golden night, earth, night, roads, fields, cold and dark. In this case, scimitar was stated in the first stanza and in the third line which symbolizes tough feeling and heart was also stated in the first stanza and in the third line which symbolizes the patience. Patch was stated in the second stanza and in the fourth line which symbolizes space of feeling Masagus Sulaiman

An Analysis of Symbolism in the Five Selected

ALSUNA Vol. 2 (1), 2019 Love Poems of Nicholas Gordon http://e-journal.ikhac.ac.id/index.php/alsuna https://doi.org/10.31538/alsuna 
emptiness, and silver bowl was stated in the fifth stanza and in the first line which symbolizes maturity of knowing the right things and the bad things.

Additionally, moon was stated in the first stanza, and in the second line symbolizes the spirit condition or readiness to do something. Golden night was stated in the second stanza, and in the second line which symbolizes the unconscious. Earth was stated in the second stanza and in the third line which symbolizes the conditions of willingness to do something really wants to. Night was stated in the second stanza and in the symbolizes the unconscious. Roads and fields were stated in the third stanza and in the first line which symbolize the journey of Life, and destination. Cold and dark were stated in the fourth stanza and in the second line which symbolize an unknown condition of something or someone about life and love. Other conventional and natural symbolisms can be also found in the 3rd love poem of Nicholas Gordon. To be obvious, Table 3 illustrates symbolisms in the 3rd love poem of Nicholas Gordon.

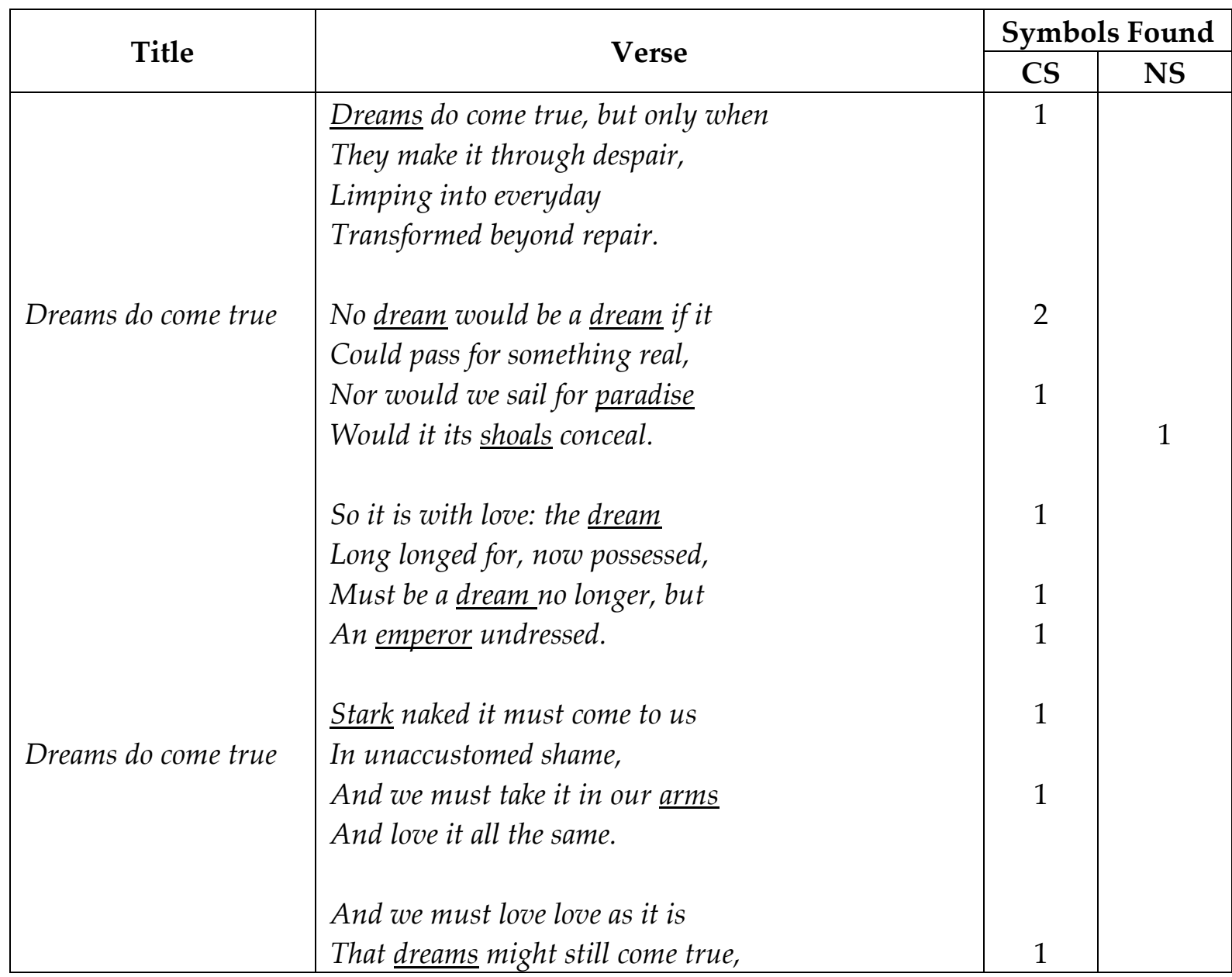

Masagus Sulaiman

An Analysis of Symbolism in the Five Selected Love Poems of Nicholas Gordon
(9) http://e-journal.ikhac.ac.id/index.php/alsuna https://doi.org/10.31538/alsuna 


\begin{tabular}{|l|l|l|l|}
\hline & $\begin{array}{l}\text { Mangled into miracles } \\
\text { To make our lives anew. }\end{array}$ & & \\
\hline
\end{tabular}

Note: CS (Conventional Symbolism), NS (Natural Symbolism)

Table 3. Symbolisms in the 3rd Love Poem of Nicholas Gordon

Table 3 shows ten conventional symbolisms and one natural symbolism. The ten conventional symbolisms were dreams, dream, dream, paradise, dream, dream, emperor, stark, arms and dreams, while one $\mathrm{n}$ atural symbolism was shoals. In this research, dreams or dream often occured in almost every stanza in different line which symbolizes the similar thing as better hopes in the future. Paradise was stated in the second stanza and in the third line which symbolizes a good place to live in. Emperor was stated in the third and in the fourth line which symbolizes feeling of powerless. Stark was stated in the fourth stanza and in the first line which symbolizes feeling of innocence and Arms were stated in the fourth stanza and in the third line which symbolizes feeling of open mind and heart. Shoals were stated in the second stanza and in the fourth line which symbolizes hidden feeling. Other conventional and natural symbolisms can be also found in the 4 th love poem of Nicholas Gordon. To be clear, Table 4 presents symbolisms in the 4 th love poem of Nicholas Gordon.

\begin{tabular}{|c|c|c|c|}
\hline \multirow{2}{*}{ Title } & \multirow{2}{*}{ Verse } & \multicolumn{2}{|c|}{ Symbols Found } \\
\hline & & CS & NS \\
\hline $\begin{array}{l}\text { Hold me to your willing } \\
\text { heart }\end{array}$ & $\begin{array}{l}\text { Hold me to your willing heart } \\
\text { And let me-help me-weep } \\
\text { That I of need might fall apart } \\
\text { And then at last might sleep. } \\
\text { Let the truth slice into me } \\
\text { That I might finally bleed } \\
\text { And purge myself of agony } \\
\text { I cannot now concede. } \\
\text { For I have bound myself in light } \\
\text { That I might live in joy, } \\
\text { And cannot-will not-let the night } \\
\text { My bonds of love destroy. }\end{array}$ & 1 & $\begin{array}{l}1 \\
1\end{array}$ \\
\hline
\end{tabular}

Masagus Sulaiman

An Analysis of Symbolism in the Five Selected Love Poems of Nicholas Gordon
(10)

$$
\begin{array}{r}
\text { http://e-journal.ikhac.ac.id/index.php/alsuna } \\
\text { https://doi.org/10.31538/alsuna }
\end{array}
$$




\begin{tabular}{|l|l|c|c|}
\hline & $\begin{array}{l}\text { And yet I know if I would gain } \\
\text { The peace for which I pray, } \\
\text { Hold me to your willing } \\
\text { I must allow the floods of pain } \\
\text { To wash my love away. }\end{array}$ & 1 \\
\hline
\end{tabular}

Note: CS (Conventional Symbolism), NS (Natural Symbolism)

Table 4. Symbolisms in the 4th Love Poem of Nicholas Gordon

Table 4 shows four conventional symbolisms and three natural symbolisms. The four conventional symbolisms were heart, sleep, agony, and bonds while the three natural symbolisms were light, night, and floods. In this case, heart was stated in the first stanza and in the first line which symbolizes willingness of affection. Sleep was stated in the first stanza and in the fourth line which symbolizes forgetfulness of problems. Agony was stated in the second stanza and in the third line which symbolizes hurt feeling and bonds was stated in third stanza and in the fourth line which symbolizes an authority.

Furthermore, light was stated in the third stanze and in the first line which symbolizes a better hope in the future. Night was stated in the third stanza and in the third line which symbolizes the unconscious. Floods were stated in the fourth stanza and in the third line which symbolizes suffering condition. Other conventional and natural symbolisms can be also found in the 5th love poem of Nicholas Gordon. To be specific, Table 5 presents symbolisms in the 5th love poem of Nicholas Gordon.

Masagus Sulaiman

An Analysis of Symbolism in the Five Selected

Love Poems of Nicholas Gordon
(11)

$$
\begin{array}{r}
\text { http:/ / e-journal.ikhac.ac.id/index.php/alsuna } \\
\text { https://doi.org/10.31538/alsuna }
\end{array}
$$




\begin{tabular}{|c|c|c|c|}
\hline \multirow{2}{*}{ Title } & \multirow{2}{*}{ Verse } & \multicolumn{2}{|c|}{ Symbols Found } \\
\hline & & CS & NS \\
\hline $\begin{array}{l}\text { How did I lose your } \\
\text { baby blue eyes? }\end{array}$ & $\begin{array}{l}\text { How did I lose your baby blue eyes } \\
\text { And the smile that lit up my sky? } \\
\text { What did I say that sent you away? } \\
\text { Can somebody tell me why? } \\
\text { Sometimes we move away from the flow } \\
\text { And find ourselves lost and alone. } \\
\text { What turn did I miss after some kiss } \\
\text { That told me what I should have known? } \\
\text { How did you get so far from my heart } \\
\text { Without my becoming aware? } \\
\text { What did you see deep inside me } \\
\text { That I never knew was there? } \\
\text { We drive in the darkness down strange empty roads } \\
\text { Into sudden and unforeseen pain. } \\
\text { We think that we choose, but after we lose, } \\
\text { We see that we've done it again. }\end{array}$ & 1 & 2 \\
\hline
\end{tabular}

Note: CS (Conventional Symbolism), NS (Natural Symbolism)

Table 5. Symbolisms in the 5th Love Poem of Nicholas Gordon

Table 5 shows three conventional symbolisms and three natural symbolisms. The three conventional symbolisms were blue eyes, kiss and heart, while the three natural symbolisms were sky, darkness and roads. In this research, blue eyes were stated in the first stanza and in the first line which symbolize the condition of whiteness and beauty. Kiss was stated in the second stanza and in the third line which symbolizes feeling of longing for, and heart was stated in the third stanza and in the first line which symbolizes willingness of affection

On the other side, sky was stated in the first stanza and in the second line which symbolizes spiritual feelings and minds. Darkness and roads were stated in the fourth stanza and in the first line. Darkness symbolizes an unpredictable condition of something or someone. Road symbolizes the journey of Life, and destination. From the data analysis of the five selected love poems of Nicholas Gordon stated, it was known that the dominant symbolisms occured

Masagus Sulaiman

An Analysis of Symbolism in the Five Selected

Love Poems of Nicholas Gordon
(12)

$$
\begin{array}{r}
\text { http://e-journal.ikhac.ac.id/index.php/alsuna } \\
\text { https://doi.org/10.31538/alsuna }
\end{array}
$$


was conventional symbolism. It can be seen from the number of symbolisms found in the five selected love poems of Nicholas Gordon stated previously. In other words, there were twenty five conventional symbolisms and there were nineteen natural symbolisms.

\section{Conclusions}

In relation to the results of previous data analysis, the researcher concluded that the conventional symbolism was more dominant than natural symbolism. In brief, there were twenty five conventional symbolisms found in the five selected love poems of Nicholas Gordon, and there were nineteen natural symbolisms found in the five selected love poems of Nicholas Gordon. In this research, In other words, four conventional symbolisms and four natural symbolisms in the first selected love poem, four conventional symbolisms and eight natural symbolisms in the second selected love poem, ten conventional symbolisms and one natural symbolism in the third selected love poem, four conventional symbolisms and three natural symbolisms in the fourth selected love poem, and three conventional symbolisms and three natural symbolisms in the fifth selected love poem.

Furthermore, the twenty five conventional symbolisms covered tear, dream (7 times stated), home, barricades, scimitar, heart (3 times stated), patch, bowl, paradise, emperor, stark, arms, sleep, agony, bonds, eyes, and kiss. Meanwhile, the nineteen natural symbolism covered night (3 times stated), light (3 times stated), stone, wind, moon, earth, roads (2 times stated), fields, cold, dark, shoals, floods, sky and darkness. In addition, the five selected love poems of Nicholas Gordon have something to do with human beings' common feelings such love relationship in terms of either happiness or sadness.

Masagus Sulaiman

An Analysis of Symbolism in the Five Selected

Love Poems of Nicholas Gordon
(13)

http://e-journal.ikhac.ac.id/index.php/alsuna https://doi.org/10.31538/alsuna 


\section{Bibliography}

Abrams, M.H. A Glossary of Literary Terms, (7th ed.). Boston: Heinle \& Heinle Thomson Learning, 1999.

Abrams, M.H., \& Harpham, G.G. A Glossary of Literary Terms, (9th ed.). Boston:Wadsworth Cengage Learning, 2009.

Ade, O. I., \& Okunoye, O. An Introduction to Literature and Literary Criticsm. Nigeria: National Open University of Nigeria, 2008.

Baldick, C. Oxford Concise Dictionary of Literary Terms. New York, NY: Oxford University Press, 2001.

Brown, H.D. Principles of Language Learning and Teaching (5th ed.). White Plains, NY: Pearson Education, Inc, 2007.

Childs, P., \& Fowler, R. The Routledge Dictionary of Literary Terms. London \& New York, NY: Rouledge Taylor \& Francis Group, 2006.

Cirlot, J.E. A Dictionary of Symbols. London: Taylor \& Francis Library, 2001.

Cuddon, J.A. A Dictionary of Literary Terms and Literary Theory. Boston: Willey Blackwell, 2013.

Gordon, N. Love Poems. New York, NY: Cafe Press, 2006.

Hamilton and Pinnegar. Self-study of Practice as a Genre of Qualitative Research: Theory, Methodology, and Practice. Netherland: Spinger, 2009.

Hornby, A.S. Oxford Advanced Learners' Dictionary: International Student's Edition (8th ed.) New York, NY: Oxford University Press, 2010. 
Indawan., Sulaiman, MGS., \& Susanti, R. Metodologi Penelitian Pendidikan Bahasa.Palembang: Roemah Sufie, 2017.

Mikics, D. A New Handbook of Literary Terms. London: Yale University Press, 2007.

Quinn, E. A Dictionary of Literary \& Thematics Terms. New York, NY: Facts on File, Inc, 2006.

Richards, C. J., Schmidt, R., Kendricks, H. \& Kim, Y. Longman Dictionary of Language Teaching and Applied Linguistics, (3th ed.). London: Longman Group Limited, 2002.

Robert, E.V., \& Jacob, H. Fiction: An Introduction to Reading and Writing. New Jersey, NJ: Prentice-Hall, Inc, 1982.

Tavakoli, H. A Dictionary of Research Methodology and Statistics in Applied Linguistics. Tehran, Iran: Tehran University, 2012

Masagus Sulaiman

An Analysis of Symbolism in the Five Selected

Love Poems of Nicholas Gordon
ALSUNA Vol. 2 (1), 2019

http://e-journal.ikhac.ac.id/index.php/alsuna https://doi.org/10.31538/alsuna 